\title{
Does Threat of Dismissal Constrain Acquisition Premium in CEO
}

\author{
Pay? \\ Swarnodeep Homroy \\ Department of Economics, Lancaster University
}

March 16, 2015

\begin{abstract}
This paper shows that the likelihood of post-acquisition CEO turnover can act as a constraint on risky acquisition decisions. The acquisition premium in pay decreases by over $50 \%$ if the dismissal risk is controlled for. Given a smaller pay premium for undertaking acquisitions and a non-zero risk of dismissal, shareholders are shown to be able to exercise some control over managerial incentives to engage in risky acquisitions through the mechanism for dismissal.
\end{abstract}

KEY WORDS: Aquisition, CEO pay, CEO turnover

JEL Codes: G34, J31, J33, M52

\section{Introduction}

A widely held proposition in the finance and economics literature is that acquisition activities are detrimental to shareholders' wealth and the profitability of the acquiring firms (Dickerson et al. 1997; Loghran and Vijh, 1997). Yet, in the last two decades there have been at least two periods of heightened acquisition activities in the US. It is conjectured that acquisitions are motivated 
primarily by managerial incentives to increase firm size and to a lesser extent by considerations of shareholder value (Jensen, 1986). This is a stylised result from the empirical literature on executive pay, which suggests that pay-size sensitivity dominates the pay-performance sensitivity (Bebchuk and Fried 2003; Bliss and Rosen, 2001; Gabaix and Landier 2008; Murphy 1999).

If pay is strongly associated with firm size, then increasing the size of the firm provides the CEO with an opportunity to increase her own pay, even if it is at the cost of shareholders' wealth. A larger firm, along with tangible benefits to CEO wealth, also generates non-pecuniary benefits to the CEO in terms of perquisites and lowering of the probability of their own firm being acquired. Given that, one way to increase firm size is to undertake acquisitions, a utility maximizing CEO may undertake acquisitions which are not in the interests of shareholders. Acquisitions also serve as signals of managerial ability and may have an impact on the long-term earnings of the CEO (Williamson 1963; Singh 1975).

Specifically, this paper asks whether the threat of post-acquisition dismissal constrains the CEO in seeking personal gain through the acquisition-premium in pay. Whilst share options are designed to discourage bad acquisitions, Harford and Li (2007) find that these to be largely ineffective. Lehn and Zhao (2006) find that $47 \%$ of CEOs of acquiring firms are replaced within 5 years of an acquisition, with dismissal being more likely if the ex-post outcome of the turnover reduces shareholders' wealth. The likelihood of dismissal should constrain the misaligned incentives of the CEO. The higher the probability of a post-acquisition dismissal, the lower is the incentive for a riskaverse CEO to undertake an acquisition. Of course, this might be offset where the wage premium is sufficiently large. Given that the agent has imperfect information of the ex-post likelihood of dismissal, the implied probability of dismissal may have a strong disincentive effect for undertaking acquisitions. 
Existing literature does not control for the likelihood of CEO turnover in estimating the acquisition premium in CEO pay. If the acquisition premium in CEO pay is a manifestation of agency problem, then the threat of dismissal should act as a constraint for undertaking risky acquisitions. Harford and $\mathrm{Li}$ (2007) allude to the possibility of survivor bias in the estimates of the acquisition pay premium. This arises from the commonly used empirical strategy to use a "sample of bidding firms whose CEOs remained in place through at least 1 year following the acquisition". The rationale for this strategy is that if a CEO is dismissed following an acquisition, a new CEO is more likely to have a higher pay, so that the pay-premium would be over-estimated (Murphy and Zabonjik, 2009). On the other hand, the exclusion of CEOs who lose their job following an acquisition induces a survivor bias in estimates of the pay-premium.

This paper controls for post-acquisition dismissal using a Heckman-type selection model. The median ex-ante severance pay eligibility within the same industry group ${ }^{1}$ is used as an exclusion restriction. The central idea is that a higher eligibility of severance pay within the same industry group will impact upon the likelihood of dismissal of an individual CEO but not on pay. This paper uses information from two waves of acquisitions, 1992-2000 and 2003-2008, to re-evaluate the managerial incentive to undertake acquisitions. By documenting the effect of dismissal risk on the acquisition premium in CEO pay, this paper extends the work of Lehn and Zhao (2006).

For a sample of 2054 acquisitions undertaken by 1119 US firms over the period 1993-2011, this paper examines the effect of the dismissal constraint on a CEO's incentive to undertake acquisition for a pay premium. The empirical evidence on whether acquisitions lead to a pay increase for the CEO is inconclusive. Some studies find that the CEOs of acquiring firms enjoy a post-acquisition

\footnotetext{
${ }^{1}$ The change in control pay is the ex-ante contracted eligibility of the CEO to receive a separation pay in the event of dismissal following an acquisition. The exclusion restriction is the median eligibility of this pay within a 2-digit industry classification. This is discussed in further details in sections $2 \& 3$.
} 
pay premium. Khorana and Zenner (1998) report that CEOs of acquiring firms receive a10.5\% pay premium compared to CEOs in comparable firms not undertaking acquisitions. The acquisition pay premium tends to persist. Harford and Li (2007) find that US CEOs enjoy post-acquisition pay premiums. Girma, Thompson and Wright (2006) report a "pure" acquisition pay premium for UK CEOs. In this strand of research, the post-acquisition premium in pay has been attributed to the signaling effect of managerial ability that is manifest in completion of acquisitions.

This paper suggests that if the likelihood of dismissal is accounted for, CEOs engaging in value-destroying acquisitions are likely to suffer a pay penalty. However, the empirical evidence on differential pay awards for good and bad acquisitions is mixed. Lambert and Larcker (1987) and Girma et al. (2006) find that CEOs engaging in bad acquisitions experience relatively lower pay. In contrast, Guest (2009) finds a positive acquisition effect on CEO pay irrespective of the effect it has on shareholders' wealth.

Extant literature focuses only on the pay incentives of CEOs to undertake acquisitions. This is the first study to examine the incentive effects of post-acquisition dismissal probability on acquisition decisions. We also examine whether the alleged pay-premium for CEOs engaging in value-destroying acquisitions persist if the likelihood of dismissal is controlled for.

Further, CEO dismissals may not be based solely on the stock market reaction to the announcement of the acquisitions. In this paper, we use a longer term metric to classify 'wealth enhancing' and 'wealth reducing' effects of acquisitions. This allows us to extend the horizon of the impact of an acquisition on shareholders wealth beyond the announcement effect.

The central focus of this paper is to examine the interplay of the incentive effects of the risk of post-acquisition dismissal and a pay premium. If the threat of dismissal has a disincentive effect on the managerial decisions to undertake acquisitions, then the risk adjusted premium in CEO 
pay should be lower than the conventional estimates. Further, the dismissal risk should rise for CEOs engaging in value-destroying acquisitions. Thus the risk-adjusted pay premium needs to be much larger for the CEO to be motivated in undertaking a risky acquisition. We examine the how probability of dismissal impacts upon the pay premium in events of value-destroying acquisitions.

Controlling for the likelihood of post-acquisition dismissal, the pay premium for acquiring CEOs fall by over $50 \%$. The fixed effect estimate of a pay premium of $4 \%$ is consistent with the findings of Bliss and Rosen (2001) and Harford and Li (2007); but that premium falls to $1.5 \%$ after controlling for dismissal probability. Whilst the results of this paper still suggest a small premium in pay for undertaking acquisitions, a risk-averse agent may not have sufficient incentives to undertake an acquisition for a marginal increase in pay given the finite risk of dismissal. Given that acquiring CEOs in our sample are $32 \%$ more likely to be dismissed, the imputed value of the pay-off for the CEO is likely to be much lesser if the risk-appetite is accounted for.

The survival-bias seems to be systematically present in both the cash and equity components of pay. This extends the study by Grinstein and Hribar (2004) who find that the acquisition pay premium is driven by large bonuses. We find evidence of survivor bias in bonus payouts. Interestingly, there seems to be no pay premium for CEOs undertaking value-destroying acquisitions if dismissal risk is accounted for. In fact, they suffer a pay penalty of $3.3 \%$. This suggests lower incentives for a CEO to undertake a risky acquisition as it might lead to both higher dismissal probability and a pay penalty.

If a long-term metric of performance is employed to classify ex-post outcomes of acquisitions, the premium in pay for acquiring CEOs is further falls by $1 \%$; and there is no significant impact on bonuses. Acquisitions that have a long-term negative impact on shareholders' wealth lead to almost $4 \%$ decrease in CEO pay. 
The paper is structured as follows: Section 2 describes the data; Section 3 examines the methodological issues and the empirical strategy. The results are presented in Section 4 and Section 5 concludes.

\section{Data}

The data used in this analysis are derived from Compustat's ExecuComp database. For the sample period 1993-2011, we use information on 2755 firms from the S\&P 1500 listings. The key variables for this analysis are described in details in the following paragraphs. Variable descriptions are presented in Table 1 and the summary statistics of key variables are presented in Table 2.

CEO dismissals are identified from the Execucomp database, Fortune 500 and Fortune 1000 lists, the Wall Street Journal and Lexis/Nexis Business news database. Consistent with the definition used by Huson, Malatesta and Parrino (2004), turnover means that a CEO who is observed in a firm on October 1st of year $t$ is not observed in the same firm on the same day of year $t+1 .{ }^{2}$ Classifying dismissal is difficult as firms rarely state that they have fired a CEO. Therefore, dismissals are identified from press reports that a CEO was fired, forced out or resigned due to internal pressures. Cases where CEOs vacate their post but continue as the chairman of the board are not treated as dismissal. The robustness of this classification technique was checked using an age-based algorithm: CEOs below 55 years of age and who leave their jobs following an acquisition are classified as having been dismissed. This method yields similar overall number of dismissals to the original method. However, using an age-based classification may over-estimate the probability of dismissal below the threshold and underestimate it otherwise. Since this might potentially bias the estimates, the original classification technique is retained.

\footnotetext{
${ }^{2}$ We use October-September cycle to overlap with the DEF 14 A filing cycles.
} 
Information on stock price performance is obtained from the Centre for Research in Securities Prices (CRSP). The annual average value weighted return for a firm is benchmarked to the average annual value weighted return of the median firm in the same 2-digit SIC code. The natural log of annual sales is used as a measure of firm size ${ }^{3}$. The risk in a firm's operating and information environment is controlled for using the volatility in annual average stock returns.

Corporate governance data was obtained from the Risk Metrics database (formerly IRRC). Corporate governance data are available for 1996-2011 and hence specifications with corporate governance controls contain fewer observations.

\section{KEY VARIABLES:}

\section{Retention}

Retention is a binary indicator for a CEO retaining her job for at least two years following an acquisition. Of the 1119 firms engaging in acquisitions, 538 (48.08\%) dismiss the acquiring CEO within the first two years of an acquisition ${ }^{4}$. In the same period, only 318 (19.43\%) of 1636 non-acquiring firms dismiss their CEO. The raw data suggest a higher probability of CEO turnover in acquiring firms. There may be a concern that acquiring firms and firms that dismiss the CEO following an acquisition may be different on some observable characteristics. To attenuate that concern, summary statistics for key variables are presented in Table 3, respectively for firms that experience post-acquisition CEO dismissal and those that do not. On average, the acquiring firms are larger than non-acquiring firms. In periods following an acquisition, CEO pay is $53.9 \%$ higher than before the acquisition. However, there is a decrease in the acquiring firm's profitability after undertaking an acquisition.

\footnotetext{
${ }^{3}$ Natural $\log$ of total assets and total market value of equity are used as alternative measures of firm size to test the robustness of the baseline results.

${ }^{4}$ The number of post-acquisition dismissals is 443 if the age-based algorithm to classify dismissals is employed.
} 


\section{Acquisitions}

Acquisition is defined as an event where a bidding firm, with less than a $10 \%$ stake at the target firm, seeks to own at least $50 \%$ of the target firm (Lehn and Zhao, 2006; Faccio, McConnell, and Stolin, 2006) ${ }^{5}$. Such events are identified from Acquisition Weekly, Thomson One Banker and Forbes company database. We follow the conventional selection method of acquisition samples used in Lehn and Zhao (2006) and Golubov, Petmezas, and Travlos (2012). We use information on successful acquisition bids by U.S. public firms announced between January, 1, 1992 and December, 31, 2010. Target firms can be U.S. firms- both public and private ${ }^{6}$. The sample is restricted to public bidders, because acquisition decisions by public firms require stronger incentives for the CEO. Public acquisitions also require more regulatory and shareholder approvals and generally exposes the CEO to greater risks (Rhee and Valdez, 2009). We exclude all restructuring, leveraged buyouts, privatization and bankruptcies leaving a sample of 24,677 events. For a meaningful acquisition, we require the size of the target firm to be at least $10 \%$ of that of the acquiring firm. This yields a sample of 15,598 events. Further, we require that the bidding firm is listed in both Execucomp and CRSP, resulting in a sample of 14,992 transactions.

Finally, a materiality constraint of non-overlapping acquisitions was necessary to isolate the lagged effects of individual acquisitions on CEO pay where a sample firm undertakes multiple closely spaced acquisitions. An overlap is defined as a gap of less than 24 months between the announcements of two acquisitions ${ }^{7}$. The final sample consists of 2,054 acquisitions undertaken by

\footnotetext{
${ }^{5}$ The event year is defined as the year of announcement of an acquisition.

${ }^{6}$ As a measure of robustness, we include acquisitions of foreign public firms by U.S. public firms. The results are discussed in section 4.3.

${ }^{7}$ Robustness check was performed including the overlapping acquisitions in the dataset. The estimate on the contemporaneous indicator for acquisition was (0.053) almost one-and-half percentage points higher than our baseline estimates and significant at $1 \%$ level. The higher estimated effect of acquisition on CEO pay possibly reflects the overlapping effects of closely timed acquisitions.
} 
1,119 firms.1,636 sample firms do not engage in any acquisitions. ${ }^{8}$

We control for the method of payment and the deal value of acquisitions. $38 \%$ acquisitions in our sample are stock-financed, $19 \%$ are cash-financed, and the remaining $43 \%$ are financed by a combination of stocks and cash. The median (mean) deal value of the acquisitions in our sample is US\$177.23 million (US\$ 1335.75 million).

\section{Good and Bad Acquisitions}

Acquisitions are evaluated on the basis of the response of the stock market to a successful bid announcement over a 7 day period $[-3,+3] .{ }^{9}$. The announcement effect is conventionally used as an indicator for the market reaction to and the impact of an acquisition on the shareholders' wealth. The abnormal returns on the acquiring firm's stocks were computed with respect to the returns on the market index. $42 \%$ of the acquisitions in the sample have positive abnormal returns and $58 \%$ acquisitions are associated with negative abnormal returns. Following Khoranna and Zenner (1998) and Girma et al. (2006), a bad acquisition is defined as an event for which $C A R[-3,+3]$ around the announcement date is negative. From Table 5, 57.5\% (1,194 out of 2,054) of sample acquisitions have negative cumulative abnormal returns in the 7 -day announcement window. ${ }^{10}$

\section{CEO Pay}

Execucomp reports a number of CEO pay measures. The conventional measure of total annual compensation is TDC1 or $\mathrm{TDC} 2^{11}$ which is the linear summation of salary, bonus, and the value of stock options, restricted stock grants, long term incentive payouts, and all other payments ${ }^{12}$.

\footnotetext{
${ }^{8} \mathrm{~A}$ further 284 transactions involve a target firm listed on overseas stock exchanges. We use this information as a measure of robustness.

${ }^{9}$ The robustness of the results was tested using $\mathrm{CAR}[-1,+1]$ and $\mathrm{CAR}[-5,+5]$ as event windows to classify bad acquisitions. The results are qualitatively similar.

${ }^{10}$ Robustness of the estimates was checked using CAR $[-5,+5]$.

${ }^{11}$ Calculation of TDC1 uses the value of option grants and the calculation of TDC2 uses the value of options exercised.

${ }^{12}$ All other payments include compensation that can't be categorised under the other heads. This may include severance payments, debt forgiveness, signing bonuses, life insurance premiums, etc.
} 
A potential concern is that severance pay may be included in the calculation of CEO pay. This concern arises from the inclusion of the aforementioned 'all other payments' ( $A L L O T H$ variable in Execucomp) in the calculation. To circumvent this problem, we exclude the 'all other payments' component from the calculation of the total annual compensation of the CEOs. Therefore our measure of CEO pay is constructed from Execucomp as TDC2-ALLOTH. ${ }^{13}$ The mean (median) annual compensation for the sample CEOs is US\$ 4.3 million (1.6 million).

\section{Severance Payment Eligibility}

Severance payment eligibility is the ex-ante contracted eligibility of the CEO to receive a payment in the event of a dismissal following an acquisition. This was instituted in the 1980s to encourage risk-taking among CEOs in the interests of the shareholder, even if it endangers their jobs. In essence, a severance package is analogous to a put option which has been shown to be effective in reducing agency conflicts (Ju, Leland, and Senbet, 2002). This is a one-off payment agreed upon at the beginning of the CEO's tenure and serves as an insurance aganist a fall in firm value. However, it is not a regulatory requirement for firms to have a provision of severance payment. Execucomp provides information on the severance payment eligibility of CEOs, which is the estimated total payments to the executive in the event of an involuntary, without-cause termination. We primarily use the "TERM_PYMT" variable reported in Execucomp and also check the robustness of our results using "CHG_CTRL_PYMT", which reports estimated payments in the event of an involuntary termination due to a change in control. All reported estimates assume that a termination occurrs on the last day of the fiscal year. Care has been taken to verify and augment the Execucomp data with hand-collected information from the DEF-14A filings of firms for each year of a new CEO appointment. $57 \%$ of sample firms provide the CEOs with an ex-ante

\footnotetext{
${ }^{13}$ We also check for the robustness of our results using $1 T D C 1-A L L O T H^{\prime}$ as the measure of CEO annual compensation.
} 
committment to severance pay, with a mean (median) of US\$1.4 million (0.6 million). ${ }^{14}$ We estimate the median severance pay for industries at 2-digit SIC levels. Potential econometric issues arising from the endogeneity of severance pay and CEO pay are discussed in section 3.

\section{Governance Variables}

Board Size and composition and CEO power is likely to impact upon the risk-taking behaviour of CEOs (Pathan, 2008). Board size is measured as the number of directors on the board. Board independence is measured using percentage of outside directors on the board. In addition, the percentage shareholding of the CEO in the firm is a likely indicator of CEO power. On the other hand, a higher percentage share ownership of the CEO may also align the interests of the CEO with that of the shareholders. Either way, it is likely to be impact upon the strength of governance. We also control for CEO tenure as another measure of CEO power.

\section{Methodology}

The central focus of this paper is to examine whether the post-acquisition dismissal probability is reflected in the acquisition pay premium. Several econometric issues need to be considered in designing an empirical strategy. A key issue is partial observability: if a CEO is dismissed post acquisition, their ex-post pay is not observed. On the other hand, if the acquisition pay premium is calculated only on surviving CEOs, it is likely to be upward biased. One approach would be to set the pay of all dismissed CEO equal to zero and estimate the pay premium. However, this might overcorrect the bias given the large drop in the pay ${ }^{15}$. In addition, it would not be possible to

\footnotetext{
${ }^{14} \mathrm{~A}$ probit test was performed to check the nature of prevalence of the change in control pay eligibility. There is insufficient evidence to suggest that firms that provide a contractual change in control pay eligibility are systematically different on observable characteristics.

${ }^{15}$ As a measure of checking the robustness of our empirical strategy, we set the pay of CEOs who are dismissed following an acquisition to be zero and estimated the acquisition pay premium. The results are presented in Appendix 1 , and suggests a large pay penalty for undertaking acquisitions.
} 
interpret lagged pay impacts of acquisitions, because the CEO would have changed. A comparison of the pre- and post-acquisition sample is provided in Table 3. Our approach is therefore to use a Heckman-type selection framework to address the partial observability issue. First, we estimate the probability of CEO retention following an acquisition. We attempt to correct for the survivor bias in the CEO acquisition pay premium by using the predicted probability of retention as an explanatory variable in the second-stage pay regressions.

A second econometric issue is to define an appropriate exclusion restriction. This is because many of the determinants of the probability of retention are also likely to impact upon CEO pay. The identification strategy of this paper is based on the median severance entitlement of CEOs in the event of a turnover caused by change in control within a 2-digit SIC level. It might be argued that the severance pay eligibility and CEO pay are co-determined at the beginning of the tenure. The implication would then be that the severance pay eligibility is not a valid instrument, even though the correlation coefficient between the ex-ante severance pay eligibility and CEO pay is 0.14 and not statistically significant at conventional levels.

We attenuate this concern by using the median ex-ante severance pay eligibility of the CEOs in a given 2-digit industry code in the event of a CEO dismissal following acquisitions. A priori, a higher industry median of severance pay eligibility is associated with a higher probability of postacquisition CEO retention; i.e. it is more expensive for firms to hire new CEOs. However, the industry median of severance pay in the same industry is unlikely to impact upon any individual CEO's pay. Severance payment is only relevant when post-acquisition CEO turnover is under consideration, and it is likely to impact upon the CEO pay only through its effect on survival probability.

It is plausible that CEOs undertake acquisitions to increase their pay whilst knowing that a 
dismissal would lead to a lump-sum payment. In that case, the eligibility of severance pay will be contributing to managerial decision making in undertaking acquisitions. Zhao (2013) suggests that severance pay provisions does not provide managers with perverse incentives in acquisition decisions. From Table 2, the median severance pay is approximately $38 \%$ of the median CEO pay, which is unlikely to motivate a CEO to undertake a risky acquisition. This is because the incentive effect of a continuous stream of high pay is likely to dominate any incentive effect of a one-off separation pay. It may yet be conceivable that in certain situations, the incentive effects are reversed: a one-off separation pay may provide more utility to the CEO than continued annual pay. This is likely to be the case for CEOs nearing retirement for whom the stream of future income is truncated. The incentives of CEOs nearing retirement are reportedly different due to shorter horizon of decision making (Antia, et al. 2010; Dechow and Sloan, 1991; Matta and Beamish, 2008). The analysis of this paper is based on the sub-sample of acquisitions not undertaken within the last two years of a CEO's tenure. Whilst this leads to a 7\% loss in the number of acquisitions, this allows us to study the incentive effects of undertaking acquisitions where the CEO's incentive horizon is not truncated by impending retirement. In short, there is no strong reason to suspect that a CEO will undertake a risky acquisition being motivated by the one-off severance pay as the better outcome.

Ideally, a test for instrument validity is useful to address any concerns about the exogeneity of the instruments. There are no readily available tests for the validity of exclusion restrictions in Heckman selection models. From Table 3, there is no significant difference in the eligibility of severance payments between the acquiring and the non-acquiring firms. To attenuate the concern that CEO pay and industry median of severance pay might co-vary, Table 4 presents the median CEO pay at different quartiles of the distribution of industry medians of severance pay. There is 
no evidence of association between the two variables ${ }^{16}$. The only significant difference of median values is for firm size: CEOs of large firms seem to have a higher severance payment eligibility.

Moreover, regression estimates of the industry average of severance pay eligibility on total CEO pay and on the probability of CEO turnover suggest that severance pay eligibility is significantly (and negatively) associated with probability of the latter ( $\mathrm{p}$ value $=0.005$ ) but has an insignificant effect on the former $(\mathrm{p}$ value $=0.244)$. All the above evidence suggests that the exclusion restriction is associated with the probability of turnover but not CEO pay. In section 4.3 , we discuss robustness checks of the exclusion restriction and the estimation technique.

In the first-stage, we estimate the probability of an acquiring CEO retaining her job after the event, using covariates for firm-level and CEO-level characteristics and entitlement of severance pay as the exclusion restriction. The baseline empirical model specification is as follows:

$$
\begin{aligned}
\text { LnPay }_{i t}= & \alpha+\beta_{1}{\text { FirmPerf } \text { ormance }_{i t}+\beta \text { Sales }_{i t}+\beta_{3} X_{i t}+\beta_{4} \text { Acquisition }_{i t}} \\
& +\beta_{5} \text { Acquisition }_{i t} * \text { Sales }_{i t}+\beta_{6} \sigma+\rho\left(\text { retention }_{i t}\right)+f_{i}+h_{t}+\varepsilon_{i t}
\end{aligned}
$$

Where observations of Payit after an acquisition is conditional on the outcome of the selection equation specified as:

$$
\text { Retention }_{i t}=\left\{\begin{array}{l}
1 \text { if } \gamma z_{i t}+\nu_{i t}>0 \\
0 \quad \text { Otherwise }
\end{array}\right.
$$

$z_{i t}$ contains all the observable parameters of firm performance, firm size, CEO tenure, corporate governance measures and industry classifications that contribute to the probability of retention of the CEO in the event of an acquisition and $\nu_{i t}$ represents the exclusion restriction.

The coefficient $\beta_{1}$ is an estimate of the effect of firm performance on CEO pay. Return on assets

\footnotetext{
${ }^{16}$ The pairwise correlation coefficient is 0.09 and is not statistically significant at conventional levels.
} 
$\left(R O A_{i t}\right)$ and Market-to-Book Value $\left(M T B V_{i t}\right)$ is used to control for firm performance. Consistent with the existing literature, historical firm performance is associated with post-acquisition pay up to two lag periods. We therefore control for two lags of firm performance (Geddes and Vinod, 1997; Girma, Thompson and Wright, 2006).

Sales $_{i t}$ is used as the measure of firm size. ${ }^{17}$ It is difficult to decompose sales into "organic sales" and increases in sales due to acquisition, particularly because data on cross border targets are often not available. $\beta_{4}$ captures the bias-corrected acquisition effect on CEO pay. If acquisitions are associated with a rise in CEO pay, the coefficients on the Acquisition $i t$ (and its lags) would show as significant and positive. Acquisition At $_{\text {is }}$ an indicator which equals ' 1 ' if an event of acquisition is announced in a given year ${ }^{18}$. The use of lagged indicators for acquisitions is expected to yield qualitatively similar results to those obtained from dynamic panel models. $\beta_{3}$ captures the effects of all other observable firm performance measures contained in the vector, $X_{i t}$. The standard deviation of monthly stock returns $(\sigma)$ over a given year is used to control for the risk in a firm's information and operating environment. $f_{i}$ and $h_{t}$ control for firm and year fixed effects, respectively. The estimation reports robust standard errors that are clustered at firm level.

It might be argued that an increase in firm size through acquisition enhances CEO incentives, given that the pay-size relationship is known to dominate pay-performance sensitivity. Therefore, we use an interaction of Acquisition $_{i t} *$ Sales $_{i t}$ to control for the size effect of acquisition.

Next, we examine whether survivor bias can account for differential pay awards for ex-post 'value-enhancing' and 'value-destroying' acquisitions. In equation (3), the baseline specification is augmented with an indicator (Negative Return $n_{i t}$ ) for bad acquisition, which equals '1' for

\footnotetext{
${ }^{17}$ Qualitatively similar results are obtained using log of Total Assets as measures of firm size.

${ }^{18}$ We do not separately control for multiple acquisitions undertaken in a given year: the indicator for Acquisition equals 1 for any number of events.
} 
$C A R[-3,+3]<0$.Further, an interaction of Negative Return $n_{i t}$ with Acquisition $_{i t}$ is added to the baseline specification. If the reported pay-premium for undertaking a bad acquisition can be accounted for by survivor-bias, the estimate of the Acquisition $i t *$ Negative Return $_{i t}$ will be statistically insignificant.

$$
\begin{aligned}
& \text { LnPay }_{i t}=\alpha+\beta_{1} R O A_{i t}+\beta_{2} \sigma_{\text {Re } t_{i t}}+\beta_{3} \text { Sales }_{i t}+\beta_{4} \text { Acquisition }_{i t}+
\end{aligned}
$$

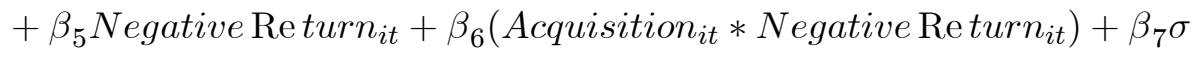

$$
\begin{aligned}
& +f_{i}+h_{t}+\varepsilon_{i t}
\end{aligned}
$$

Finally, the mechanism of the acquisition premium in CEO pay may be a consequence of higher bonus payouts (Grinstein and Hribar, 2004). To examine the survivor bias in disaggregated measures of pay, the baseline specification was re-estimated using bonus as the dependent variable. If there is no survivor bias in bonus, it would appear that the post-acquisition pay premium is manifest in bonus payouts.

\section{Results And Analysis}

\subsection{Is there a Survivor Bias in the acquisition premium in CEO pay?}

In Table 6, column (1) presents the results of the selection equation and column (2) reports the estimates from outcome equation. Column (3) presents the fixed effects estimates of the impact of acquisitions on CEO pay without correcting for survivor-bias. The Wald test of independent equations $\left(H_{0}: \rho=0\right)$ tests if the Heckman selection model is appropriate for the system of equations. The association parameter for our system of equations is positive $(\rho=0.215)$ and statistically significant (robust standard error $=0.0402$ ): any parameter that increases the probability of retention 
in the event of an acquisition also increases the post-acquisition CEO pay.

From the first-stage estimation, the exclusion restriction is significant and positive, which supports the hypothesis that a higher industry average of severance payment eligibility lowers the probability of CEO turnover. ${ }^{19}$ More importantly, acquiring CEOs seem to have a higher likelihood of turnover. Acquiring CEOs are 35\% less likely to be retained compared to their non-acquiring counterparts. The likelihood of turnover is significant in the year following an acquisition. These suggest that the likelihood of post-acquisition turnover may carry incentive effects for undertaking acquisitions. The size and composition of the board significantly affects the likelihood of retention: large boards with a lower percentage of outside directors are less likely to dismiss a CEO. A higher percentage share ownership of the CEO also decreases the likelihood of dismissal.

The impact of the predicted probability of dismissal is used in estimating the acquisition pay premium. Not surprisingly, there is a positive and statistically significant association between probability of retention and pay. The focus of this analysis is the impact of acquisition on pay when the probability of retention is controlled for. Undertaking an acquisition leads to a $1.7 \%$ increase in CEO pay, and the acquisition pay premium persists in the year following an acquisition. However, this estimate of the acquisition pay premium is significantly lower than the fixed effects estimates ( $\sim 4$ pp.) as presented in column (3). The "pure" acquisition premium in pay is reduced by over $50 \%$ when the likelihood of post-acquisition turnover is controlled for. There seems to be a survivor bias in the standard fixed effects estimates of the acquisition premium. Given a non-zero risk of dismissal following an acquisition (Lehn and Zhao, 2006), the small pay premium of $1.8 \%$ may be insufficiently strong as an incentive for a risk-neutral CEO to undertake an acquisition. The estimate of Acquisition $_{i t} *$ TotalAssets $_{i t}$ is positive and significant, suggesting that CEOs do

\footnotetext{
${ }^{19}$ This result is robust to the severance pay variable used. Both TERM_PYMT and CHG_CTRL_PYMT produce similar estimates.
} 
gain in pay for the increase in firm size through acquisition ${ }^{20}$. However, the magnitude of the effect is of similar order of magnitude as the "pure" acquisition premium in pay. Therefore we expect them to have similar incentive effects.

The estimates on covariates for firm size, firm performance and board characteristics are consistent with earlier literature: CEO pay is higher in larger firms with large and less independent boards. Further, it is of interest to understand how the survivor bias affects disaggregated measures of pay. We examine the survivor bias in the post-acquisition CEO bonus. The results are presented in Table 7: estimates of the bias-corrected premium are presented in column (2). There is a $2 \%$ premium in bonus for acquiring CEOs, which persists for the year following acquisitions. The fixed effects estimate of the acquisition premium in bonus is $5.1 \%$ as presented in column (3). The premium in bonus payouts is reduced by $\sim 60 \%$ when the likelihood of post-acquisition turnover is controlled for. It seems that the survivor bias in the acquisition premia is systematic across different measures of pay awards. All other covariates retain their expected sign and significance.

\subsection{Does survivor bias account for the pay premium for bad acquisitions?}

To examine how survivor bias affects post-acquisition pay premium for CEOs undertaking bad acquisitions, the baseline specification is augmented with Negative Re turn $_{i t}$ and Acquisition $_{i t} *$ Negative Re turn $_{i t}$. The objective is to investigate further if good and bad acquisitions are similarly rewarded, providing the $\mathrm{CEO}$ with an incentive to engage in value-destroying acquisitions. If there is survivor-bias in the acquisition pay premium for CEOs engaging in value-destroying acquisitions, then the incentive effects of undertaking risky acquisitions for pay increase are further reduced. The results are presented in Table 8 .

\footnotetext{
${ }^{20}$ The results are qualitatively similar for the alternative measures of firm performance.
} 
The estimate of Negative Return $i t$ is negative and borderline significant at the $5 \%$ level. The coefficient of the interaction term Acquisition $_{i t} *$ Negative Return $_{i t}$ is negative and significant: CEOs undertaking bad acquisitions suffer a contemporaneous pay decrease. These results suggest that risky acquisitions may not result in any pay gain for the CEO and if the likelihood of postacquisition dismissal is controlled for, CEOs engaging in acquisitions that do not gain the approval of the market are likely to be penalised. This result is not consistent with the managerial power theory which suggests that CEOs are rewarded for undertaking an acquisition, irrespective of the ex-post financial outcome of the event. This suggests an important limitation to the motivations of a CEO in undertaking an acquisition. Under imperfect information about the ex-post likelihood of dismissal and possible pay loss, a utility maximizing risk-averse CEO has little monetary incentive to undertake a risky acquisition. It appears that the likelihood of post-acquisition dismissal acts as a tool of incentive alignment.

Finally, using Cumulative Abnormal Returns $(\mathrm{CAR}[-3,+3])$ around the announcement date to categorize 'value-enhancing' and 'value-destroying' acquisitions may provide a short-term statistic to estimate the wealth effects of an acquisition. The horizon of the performance effect of the acquisition and the unvested equity options of the CEO may extend beyond the announcement effect (Vijh 1997; Rau and Vermaelen, 1998). To control for the long-term impact of acquisitions, we use the annualised value-weighted returns of a firm benchmarked to similar firms. The benchmarking is done by sorting sample firms into quartiles of size and value (MTBV) within the 2-digit SIC-code. A sample firm's annualized returns are benchmarked to the median of that of the firms that are included in exactly the same sub-groups for both the variable. If the benchmarked return in an event year is negative, the event is classified as a bad acquisition. The indicator NegativeValueWeighted Return $n_{i t}$ equals '1' if the annual value weighted return of the acquiring 
firm is lower than the value weighted return of the median firm in the same 2-digit SIC code. The results presented in Table 9 are qualitatively similar to the baseline estimates. It appears that the results are not driven by the empirical strategy to classify bad acquisitions.

\subsection{Robustness Issues}

We undertake a range of robustness checks for our baseline estimates. The acquiring firms may not be a randomly selected subsample and the decisions to undertake acquisitions may be endogenous. If the omitted variables simultaneously impact upon acquisition decisions and the pay premium, the baseline estimates are potentially biased. We seek to circumvent this problem in two ways. First, we use firm fixed effects to mitigate potential bias due to time invariant omitted variables. Secondly, the probability of a firm undertaking an acquisition is instrumented using CEO tenure and an indicator for whether the firm has undertaken acquisition(s) in the previous two years. AcquisitionHistory equals ' 1 ' if a sample firm has undertaken one or more acquisition in the previous two years and '0' otherwise. We chose these instruments because CEO tenure may affect the entrenchment of the CEO and hence his decision to undertake an acquisition. Similarly, prior acquisition history may be a predictor of the likelihood of future acquisitions. This instrumentation strategy yields estimates that are qualitatively similar to the fixed effects ${ }^{21}$. The results are available but is not presented here in the interests of brevity.

The acquisition pay premium may vary by the size of the acquisition deal and the mode of financing. We control for the nature of financing of the acquisition and the deal size. A larger deal is associated with higher CEO pay but the main results appear not to be affected by the deal size and the mode of acquisition financing. The results are presented in Appendix 2.

\footnotetext{
${ }^{21}$ We also check the robustness of our results using the interaction of the industry average severance pay eligibility and firm size as the exclusion restriction. The results are qualitatively similar to the baseline estimates.
} 
Further, it may be argued that the incentive effects of NegativeReturn ${ }_{i t}$ are non-linear: meaningful incentives only stem from larger negative abnormal returns. Therefore to include only statistically meaningful effects, we reclassify bad acquisitions as those for which NegativeReturn $n_{i t}$ is above the 25 th percentile. The point estimate of the reclassified Acquisition $_{i t} *$ NegativeReturn $_{i t}$ is larger $(7.8 \%$ compared to $3.3 \%$ in the baseline estimate) and is significant at the $5 \%$ level. The results are presented in the Appendix.3.

There might also be concern that the mean severance pay eligibility is correlated with other industry level variations that might impact pay. We estimate the system of equations (1) and (2) with industry fixed effects rather than firm fixed effects. The results are qualitatively similar to our baseline estimates. Finally, we also test if the results vary for diversifying acquisitions. Once again, the results are very similar to our baseline estimates. The results are omitted in the interests of brevity.

\section{Conclusion}

This paper examines survivor bias in the CEO acquisition pay premium for a large sample of US firms over the period 1993-2011. Controlling for the likelihood of post-acquisition takeover, we find evidence of survivor bias in earlier estimates of the acquisition pay premium. Consistent with the extant literature, we find that acquiring CEOs are paid more than their non-acquiring counterparts but that the magnitude of the pay premium is reduced by over $50 \%$ if the likelihood of post-acquisition CEO turnover is controlled for. If survivor bias is corrected for, there is no pay

premium for a CEO engaging in a value-destroying acquisition, and indeed, she suffers a decline in pay.

Given that the likelihood of post-acquisition dismissal is not known to the risk-averse CEO 
ex-ante and that in controlling for this likelihood, the pay premium is quite small, the managerial incentive to undertake risky acquisitions is low. Moreover, controlling for dismissal risk, there is no premium in pay for a CEO who undertakes a value-destroying acquisition. These results contradict the managerial power hypothesis. If a CEO has little incentive in undertaking a risky acquisition to increase pay, an interesting area for future research is to examine competing hypotheses to explain the decision making of managers in undertaking risky acquisitions.

It is worth noting that the results of this paper are in no way suggestive of an efficient principalagent arrangement. CEOs routinely undertake risky and value-destroying acquisitions. This paper contributes to the literature in suggesting that incentives for undertaking bad decisions may lie elsewhere and that pay enhancement may not be a sufficiently strong motivation if the likelihood of dismissal is accounted for. Future research could focus on non-monetary incentives for undertaking acquisitions. This paper further contributes to the literature by suggesting that shareholders are able to exercise some control over managerial incentives to engage in risky acquisitions through the mechanism for dismissal. 


\section{References}

[1] Anderson, C., Becher, D. and Campbell, T. (2004) Bank Mergers, the market for Bank CEOs and Managerial Incentives, Journal of Financial Intermediation, 13, 6-28.

[2] Antia, M., Pantzalis, C., Park, J.C. (2010) CEO Decision Horizon and Firm Performance: An Empirical Investigation, Journal of Corporate Finance, 16, 288-301.

[3] Bebchuk, L.A. and Fried, J.M. (2003). Executive Compensation as an Agency Problem, The Journal of Economic Perspectives, 17(3), 71-92.

[4] Bijzak, J., Lemmon, M. and Naveen, L. (2008) Does the use of Peer Group lead to Higher Pay and Less Efficient Compensation, Journal of Financial Economics, 90, 152-168.

[5] Bliss, R.T and Rosen, R.J (2001), CEO Compensation and Bank Mergers, Journal of Financial Economics, 61(1), 107-138.

[6] Conn, R., Cosh, A., Guest, P. and Hughes, A. (2004) Why must all good things come to an end? The Performance of Multiple Acquirers. In Academy of Management (eds.), Creating Actionable Knowledge, Best Paper Proceedings, vol. 64. New Orleans: Academy of Management

[7] Core, J.E., Holthausen, R.W. and Larcker, D.F. (1999) Corporate Governance, Chief Executive Officer Compensation and Firm Performance, Journal of Financial Economics, 51, 371-406.

[8] Dechow, P.M. and Sloan, R.G. (1991)Executive Incentives and the Horizon Problem: An Empirical Investigation, Journal of Accounting and Economics, 14(1), 51-89.

[9] Dickerson, A.P., Gibson, H.D., and Tsakalotos, E. (1997) The Impact of Acquisitions on Company Performance: Evidence from a Large panel of U.K. Firms, Oxford Economic Papers, $49,344-361$. 
[10] Faccio, M., McConnell, J.J., and Stolin, D. (2006) Returns to acquirers of listed and unlisted targets, Journal of Financial \& Quantitative Analysis, 41, 197-220.

[11] Gabaix, X. and Landier, A. (2008) Why has CEO Pay Increased So Much? Quarterly Journal of Economics, 123(1), 49-100.

[12] Geddes, R.R. and Vinod, H.D. (1997) CEO Age and Outside Directors: A Hazard Analysis, Review of Industrial Organization, 12(5-6), 767-780.

[13] Girma, S., Thompson, S. and Wright, P. (2006) The Impact of Merger Activity on Executive Pay in the UK, Economica, 73, 321-41.

[14] Grinstein, Y and Hribar, P (2004). CEO Compensation and Incentives: Evidence from M\&A bonuses, Journal of Financial Economics, 73(1), 119-143.

[15] Golubov, A., Petmezas, D. and Travlos, N. G. (2012) When It Pays to Pay Your Investment Banker: New Evidence on the Role of Financial Advisors in M\&As, Journal of Finance, 67(1): $271-311$.

[16] Guest, P. (2009). The Impact of Mergers and Acquisitions on Executive Pay in United Kingdom, Economica, 76, 149-175

[17] Harford, J. (2003) Takeover Bids and Target Directors' Incentives: Retention, Experience and Settling-Up, Journal of Financial Economics, 69, 51-83.

[18] Harford, J and Li, K. (2007) Decoupling CEO Wealth and Firm Performance: The Case of Acquiring CEOs, Journal of Finance, 62(2), 917-949.

[19] Heckman, J. (1979) Sample Selection Bias as a Specification Error, Econometrica, 47, 153-161. 
[20] Hughes, A. (1989) Mergers and Economic Performance in the UK: A Survey of the Empirical Evidence 1950-1990, In M, Bishop and J, Kay (eds.), European Mergers and Merger Policy, Oxford University Press.

[21] Huson, M.R.,Malatesta, P.H., and Parrino, R. (2004) Managerial Succession and Firm Performance, Journal of Financial Economics,74, 237-275.

[22] Jensen, M.C. (1986) Agency Costs of Free Cash Flow, Corporate Finance and Takeovers, American Economic Review, 76(2), 323-329.

[23] Ju, N., Leland, H.E., and Senbet, L.W. (2002) Options, Option Repricing and Severance Packages in Managerial Compensation: Their Effects on Corporate Risk, Working Paper, Available at SSRN:http://papers.ssrn.com/sol3/papers.cfm?abstract_id=346920

[24] Khoranna, A. and Zenner, M. (1998). Executive Compensation of Large Acquirers in the 1980s, Journal of Corporate Finance, 4, 209-240.

[25] Lambert, R.A. and Larcker, D.F. (1987) Executive Compensation Effects of Large Corporate Acquisitions, Journal of Accounting and Public Policy, 6, 231-43.

[26] Lehn, K.M. and Zhao, M (2006) CEO Turnover after Acquisitions: Are Bad Bidders Fired?, Journal of Finance, 61(4), 1759-1811

[27] Loghran, T. and Vijh, A.M. (1997) Do Long-Term Shareholders Benefit from Corporate Acquisitions, Journal of Finance, 52, 1765-1790.

[28] Main, B.G.M, O’Reilly, C.A. and Wade, J. (1993) Top Executive Pay: Tournament or Teamwork?, Journal of Labour Economics, 11(4), 606-628. 
[29] Matta, E. and Beamish, P.W. (2008) The Accentuated CEO Career Horizon Problem: Evidence from International Acquisitions, Strategic Management Journal, 29(7), 683-700.

[30] Murphy, K.J. (1999). Executive Compensation. In O. Ashenfelter and D. Card (eds.), Handbook of Labor Economics, Amsterdam: North Holland.

[31] Murphy, K.J. and Zabonjik, J. (2004) CEO Pay and Appointments: A Market-Based Explanations for the Recent Trends, American Economic Review, 94(2), 192-196

[32] Ozkan, N. (2012) Do CEOs gain More in Foreign Acquisitions than Domestic Acquisitions? Journal of Banking and Finance, 36(4), 1122-1138.

[33] Pathan, S. (2008) strong Boards, CEO Power and Bank Risk-Taking, Journal of Banking and Finance, 33(7), 1340-1350.

[34] Rhee, M, and Valdez, M.E. (2009) Contextual factors surrounding reputation damage with potential implications for reputation repair, Academy of Management Review, 34, 146-168.

[35] Sartori, A. (2003) An Estimator for Some Binary-Outcome Selection Models Without Exclusion Restrictions, Political Analysis, 11, 111-138.

[36] Singh, A. (1975), Take-overs, Economic Natural Selection, and the Theory of The Firm: Evidence from the Postwar United Kingdom Experience, Economic Journal, 85(339), 497-515.

[37] Williamson, O.E. (1963) Managerial Discretion and Business Behaviour, American Economic Review, 53, 1032-57.

[38] Zhao, J. (2013) Entrenchment or Incentive? CEO Employment Contracts and Acquisition Decisions, Journal of Corporate Finance, 22, 124-152. 


\section{Table 1: Variable Description and Sources}

In this table, we describe the key variables used in the empirical analysis and the sources of the data. The main databases used are WRDS Execucomp, CRSP and Risk Metrics.

\begin{tabular}{|c|c|c|}
\hline Variables & Descriptions & Source \\
\hline Retention & Indicator for event of CEO is retained following acquisition & Execucomp \\
\hline Tenure & Length of CEO tenure in a firm (in Years) & Execucomp \\
\hline CEO Pay & $\begin{array}{l}\text { Salary }+ \text { Bonus }+ \text { Value of options }+ \text { LTIP }+ \text { RSU } \\
\text { in '000 US\$ }\end{array}$ & Execucomp \\
\hline $\begin{array}{l}\text { Value Weighted } \\
\text { Return }\end{array}$ & $\begin{array}{l}\text { Weighted average of all stock returns, weights given by } \\
\text { the market value of the stock issue (price }{ }^{*} \text { shares outstanding) } \\
\text { at the end of the previous trading period. }\end{array}$ & CRSP \\
\hline Benchmarked Value & Difference in firm's annual value weighted return to & Author's \\
\hline Weighted Return & that of the median firm in the matched comparators. & Calculation \\
\hline$\sigma$ & Standard Deviation of the annual stock prices & $\begin{array}{l}\text { Author's } \\
\text { Calculation }\end{array}$ \\
\hline Acquisition & $\begin{array}{l}\text { Event by which a firm increases its voting shares in another } \\
\text { firm to } 50 \% \text { or more. }\end{array}$ & $\begin{array}{l}\text { Multiple } \\
\text { Sources }\end{array}$ \\
\hline Firm Size & Natural log of Sales & Execucomp \\
\hline Severance Payment & Ex-Ante Contracted Severance Pay entitlement of the CEO & Execucomp \\
\hline Eligibility & in events of turnover following acquisitions, '000 US\$ & DEF $14 \mathrm{~A}$ \\
\hline Percentage Share & Percentage of equity holdings of an & Execucomp \\
\hline Ownership & individual $\mathrm{CEO}$ in a firm & \\
\hline Board Size & Number of Directors on a board & RiskMetrics \\
\hline Board Independence & Percentage of outside Directors on the board & RiskMetrics \\
\hline
\end{tabular}




\section{Table 2: Summary Statistics of Key Variables}

This table presents the descriptive statistics of key variables for the full sample period

The key variables of interest are CEO Pay and Severance payment

eligibility.

\begin{tabular}{|c|c|c|c|c|c|c|}
\hline & $\mathrm{N}$ & Mean & Median & $\mathrm{SD}$ & Max & Min \\
\hline CEO pay ('000 US\$) & 16621 & 4306.51 & 1604.09 & 10257.00 & 295136.40 & 0.01 \\
\hline ROA ('000 US\$) & 16621 & 2.49 & 3.76 & 42.69 & 3551.35 & -1314.88 \\
\hline Average Value & 16265 & 0.0041 & 0.0111 & 0.0488 & 0.1105 & -0.1846 \\
\hline \multicolumn{7}{|l|}{ weighted Return } \\
\hline Severance & 16581 & 1411.34 & 614.01 & 787.56 & 241089.80 & 0.00 \\
\hline \multicolumn{7}{|l|}{ Payment ('000 US\$) } \\
\hline Sale ('000 US\$) & 16621 & 4090.80 & 902.71 & 13799.02 & 42507189.00 & 0.03 \\
\hline CEO Share & 16544 & 0.7031 & 0.00 & 3.84 & 88.20 & 0.00 \\
\hline \multicolumn{7}{|l|}{ Ownership (\%) } \\
\hline Board Size & 13022 & 9.48 & 9.03 & 2.65 & 34.00 & 3.00 \\
\hline Outside Directors (\%) & 13022 & 70.40 & 71.34 & 16.88 & 92.30 & 55.60 \\
\hline
\end{tabular}




\section{Table 3: Summary Statistics of Key Variables}

\section{Following Acquisitions}

This table presents the summary statistics for acquiring and non-acquiring firms to address potential endogeneity in undertaking acquisitions. The summary statistics for the Control Group of firms and acquiring firms in periods before acquisitions are qualitatively similar.

\begin{tabular}{|c|c|c|c|c|c|c|}
\hline \multirow[b]{3}{*}{ Variables } & \multicolumn{4}{|c|}{ Acquiring Firms } & \multicolumn{2}{|c|}{ Control Group } \\
\hline & \multicolumn{2}{|c|}{ Periods Before Acquisition } & \multicolumn{2}{|c|}{ Periods After Acquisition } & \multirow[b]{2}{*}{ Mean } & \multirow[b]{2}{*}{ Std. Dev } \\
\hline & Mean & Std. Dev & Mean & Std. Dev. & & \\
\hline $\mathrm{ROA}_{i t}$ & 2.99 & 21.75 & 2.07 & 15.33 & 2.34 & 34.28 \\
\hline $\mathrm{MTBV}_{i t}$ & 2.45 & 5.71 & 2.12 & 5.90 & 2.48 & 4.88 \\
\hline CEO Pay & 3687.44 & 1323.46 & 5722.05 & 2202.39 & 3204.10 & 945.43 \\
\hline Sales & 4324.26 & 5442.80 & 7210.76 & 4865.22 & 3123.11 & 3553.04 \\
\hline Severance Pay & 3230.58 & 1076.23 & 3314.44 & 1187.93 & 3157.56 & 2544.50 \\
\hline
\end{tabular}




\section{Table 4: Distribution of Key Variables with}

\section{Severance Pay Eligibility}

This table presents the median values of key variables at different quartiles of eligibility of severance payment. There seems to be no evidence to suggest that the median CEO pay co-varies with severance payment. The only significant difference is in median firm size, suggesting that CEOs of larger firms have a higher eligibility of severance payment. The significant differences are highlighted by $*$.

\begin{tabular}{|c|c|c|c|c|c|c|c|}
\hline \multirow[b]{2}{*}{ Variable } & \multicolumn{5}{|c|}{ Severance Payment Eligibility } & \multirow[b]{2}{*}{ Difference } & \multirow[b]{2}{*}{ p-value } \\
\hline & $0-25 \%$ & $25-50 \%$ & Difference & p-value & $50-75 \%$ & & \\
\hline Median CEO Pay & 1311.62 & 1400.82 & 89.2 & 0.173 & 1513.47 & 112.65 & 0.194 \\
\hline Median ROA & 3.66 & 3.70 & 0.4 & 0.230 & 3.77 & 0.7 & 0.251 \\
\hline Median MTBV & 2.06 & 2.44 & 0.38 & 0.188 & 2.93 & 0.49 & 0.175 \\
\hline Median Sale & 774.13 & 6899.40 & $6125.27^{*}$ & 0.032 & 14348.00 & $7448.6^{*}$ & 0.040 \\
\hline
\end{tabular}




\title{
Table 5: Distribution of
}

\section{Acquisitions Across Time}

\begin{abstract}
In this table, we present the distribution of
acquisitions and acquisitions with negative

announcement effect over sample period.
\end{abstract}

\begin{tabular}{|c|c|c|}
\hline Year & FullSample & Negative CAR $[-3,+3]$ \\
\hline & Frequency & Frequency \\
\hline 1993 & 41 & 19 \\
\hline 1994 & 66 & 34 \\
\hline 1995 & 79 & 43 \\
\hline 1996 & 153 & 90 \\
\hline 1997 & 196 & 102 \\
\hline 1998 & 184 & 108 \\
\hline 1999 & 168 & 119 \\
\hline 2000 & 139 & 79 \\
\hline 2001 & 97 & 51 \\
\hline 2002 & 72 & 46 \\
\hline 2003 & 60 & 36 \\
\hline 2004 & 121 & 77 \\
\hline 2005 & 147 & 86 \\
\hline 2006 & 160 & 94 \\
\hline 2007 & 129 & 88 \\
\hline 2008 & 78 & 35 \\
\hline 2009 & 55 & 29 \\
\hline 2010 & 53 & 25 \\
\hline 2011 & 56 & 33 \\
\hline Total & 2054 & 1194 \\
\hline
\end{tabular}




\section{Table 6: Bias-Corrected Acquisition Premium in CEO Pay}

In this table we present the estimates of acquisition premium in CEO pay, correcting for survivor bias. In columns (1) and (2) we present the estimates of the Heckman Selection model and in column (3) we report the fixed effects estimates. The dependant variables for each column is mentioned below. *,**, *** indicate significance at 10\%, $5 \%$ and $1 \%$ levels respectively. The p-values are given in the brackets.

\begin{tabular}{|c|c|c|c|}
\hline \multirow[b]{2}{*}{ Parameters } & \multicolumn{2}{|c|}{ Survivor bias Corrected } & \multirow{2}{*}{$\begin{array}{c}\text { Fixed Effects } \\
\text { (3) }\end{array}$} \\
\hline & $\begin{array}{l}\text { Selection } \\
\text { Equation } \\
(1)\end{array}$ & $\begin{array}{c}\text { Heckman } \\
\text { Corrected } \\
\quad(2)\end{array}$ & \\
\hline $\begin{array}{l}\text { Dependent } \\
\text { Variable }\end{array}$ & CEO Retention & Log Pay & Log Pay \\
\hline $\mathrm{ROA}_{i t}$ & $\begin{array}{r}0.041^{* * *} \\
(0.000)\end{array}$ & $\begin{array}{c}0.015^{*} \\
(0.049)\end{array}$ & $\begin{array}{c}0.038^{*} \\
(0.071)\end{array}$ \\
\hline $\mathrm{ROA}_{i t-1}$ & $0.033^{* *}$ & $\begin{array}{r}0.023 \\
(0.233)\end{array}$ & $\begin{array}{r}0.016^{*} \\
(0.064)\end{array}$ \\
\hline $\mathrm{MTBV}_{i t}$ & $\begin{array}{l}0.020^{*} \\
(0.055)\end{array}$ & $\begin{array}{l}0.008^{*} \\
(0.057)\end{array}$ & $\begin{array}{l}0.005^{*} \\
(0.081)\end{array}$ \\
\hline $\operatorname{MTBV}_{i t-1}$ & $\begin{array}{r}0.013 \\
(0.272)\end{array}$ & $\begin{array}{r}0.000 \\
(0.231)\end{array}$ & $\begin{array}{r}0.001 \\
(0.248)\end{array}$ \\
\hline$\sigma$ & $\begin{array}{l}-0.011^{*} \\
(0.052)\end{array}$ & $\begin{array}{r}0.126^{* *} \\
(0.003)\end{array}$ & $\begin{array}{l}0.114^{* *} \\
(0.007)\end{array}$ \\
\hline $\begin{array}{l}\text { Firm Size } \\
\text { (Ln Sales) }\end{array}$ & $\begin{array}{r}0.031^{*} \\
(0.066)\end{array}$ & $\begin{array}{r}0.364^{* * *} \\
(0.000)\end{array}$ & $\begin{array}{r}0.391^{* * * *} \\
(0.000)\end{array}$ \\
\hline Acquisition $_{i t}$ & $\begin{array}{r}-0.325^{* * *} \\
(0.000)\end{array}$ & $\begin{array}{r}0.015^{* *} \\
(0.010)\end{array}$ & $\begin{array}{r}0.038^{* *} \\
(0.013)\end{array}$ \\
\hline Acquisition $_{i t} *$ & 0.003 & $0.061^{*}$ & $0.019^{* *}$ \\
\hline Firm Size & $(0.376)$ & $(0.058)$ & $(0.018)$ \\
\hline Acquisition $_{i t-1}$ & $\begin{array}{r}-0.281^{* *} \\
(0.024)\end{array}$ & $\begin{array}{r}0.018^{* *} \\
(0.011)\end{array}$ & $\begin{array}{r}0.031^{* *} \\
(0.025)\end{array}$ \\
\hline Acquisition $_{i t-2}$ & $\begin{array}{r}-0.021 \\
(0.233)\end{array}$ & $\begin{array}{l}0.009^{*} \\
(0.053)\end{array}$ & $\begin{array}{r}0.019^{* *} \\
(0.008)\end{array}$ \\
\hline Severance & $0.026^{* *}$ & & 0.012 \\
\hline Pay & $(0.042)$ & & $(0.309)$ \\
\hline CEO Tenure & $\begin{array}{r}0.000 \\
(0.112)\end{array}$ & $\begin{array}{c}0.001^{*} \\
(0.088)\end{array}$ & $\begin{array}{r}0.009^{* *} \\
(0.040)\end{array}$ \\
\hline $\begin{array}{l}\text { Percentage Share } \\
\text { Ownership }\end{array}$ & $0.011^{* *}$ & $\begin{array}{r}0.004^{* *} \\
(0.010)\end{array}$ & $\begin{array}{r}0.007^{* *} \\
(0.002)\end{array}$ \\
\hline Board Size & $\begin{array}{r}0.949^{* *} \\
(0.009)\end{array}$ & $\begin{array}{r}0.127^{* *} \\
(0.012)\end{array}$ & $\begin{array}{r}0.028^{* * *} \\
(0.000)\end{array}$ \\
\hline $\begin{array}{l}\text { Board } \\
\text { Independence }\end{array}$ & $\begin{array}{r}-1.121^{* *} \\
(0.036)\end{array}$ & $\begin{array}{r}-0.051^{* *} \\
(0.016)\end{array}$ & $\begin{array}{r}-0.034^{* *} \\
(0.016)\end{array}$ \\
\hline $\begin{array}{l}\text { No. of Observations } \\
\rho\end{array}$ & $\begin{array}{r}13022 \\
0.229\end{array}$ & 13022 & 13022 \\
\hline
\end{tabular}




\section{Table 7: Bias-Corrected Acquisition Premium in CEO Bonus}

In this table we present the estimates of survivor. bias in the post-acquisition bonus pay. In columns (1) and (2) we present the estimates of the Heckman Selection model and in column (3) we report the fixed effects estimates. The dependant variables for each column is mentioned below. *, **, *** indicate significance at $10 \%, 5 \%$ and $1 \%$ levels respectively. The $\mathrm{p}-$ values are given in the brackets.

\begin{tabular}{|c|c|c|c|}
\hline \multirow[b]{2}{*}{ Parameters } & \multicolumn{2}{|c|}{ Survivor bias Corrected } & \multirow{2}{*}{$\begin{array}{c}\text { Fixed Effects } \\
(3)\end{array}$} \\
\hline & $\begin{array}{c}\text { Selection } \\
\text { Equation } \\
\quad(1)\end{array}$ & $\begin{array}{c}\text { Heckman } \\
\text { Corrected } \\
\quad(2)\end{array}$ & \\
\hline $\begin{array}{l}\text { Dependent } \\
\text { Variable }\end{array}$ & CEO Retention & Log Bonus & Log Bonus \\
\hline $\mathrm{ROA}_{i t}$ & $\begin{array}{r}0.041^{* * *} \\
(0.000)\end{array}$ & $\begin{array}{r}0.016^{* *} \\
(0.050)\end{array}$ & $\begin{array}{c}0.037^{*} \\
(0.058)\end{array}$ \\
\hline $\mathrm{ROA}_{i t-1}$ & $\begin{array}{r}0.033^{* *} \\
(0.011)\end{array}$ & $\begin{array}{r}0.019 \\
(0.319)\end{array}$ & $\begin{array}{r}0.018^{*} \\
(0.060)\end{array}$ \\
\hline $\mathrm{MTBV}_{i t}$ & $\begin{array}{r}0.020^{*} \\
(0.055)\end{array}$ & $\begin{array}{r}0.008^{*} \\
(0.056)\end{array}$ & $\begin{array}{c}0.007^{* *} \\
(0.049)\end{array}$ \\
\hline $\mathrm{MTBV}_{i t-1}$ & $\begin{array}{r}0.013 \\
(0.272)\end{array}$ & $\begin{array}{r}0.001 \\
(0.248)\end{array}$ & $\begin{array}{r}0.000 \\
(0.240)\end{array}$ \\
\hline$\sigma_{\operatorname{Re} t}$ & $\begin{array}{l}-0.011^{*} \\
(0.052)\end{array}$ & $\begin{array}{r}0.122^{* *} \\
(0.012)\end{array}$ & $\begin{array}{r}0.198^{* *} \\
(0.009)\end{array}$ \\
\hline $\begin{array}{l}\text { Firm Size } \\
\text { (Ln Sales) }\end{array}$ & $\begin{array}{c}0.031^{*} \\
(0.066)\end{array}$ & $\begin{array}{r}0.403^{* * *} \\
(0.000)\end{array}$ & $\begin{array}{r}0.454^{* * *} \\
(0.000)\end{array}$ \\
\hline Acquisition $_{i t}$ & $\begin{array}{r}-0.325^{* * *} \\
(0.000)\end{array}$ & $\begin{array}{r}0.020^{* * *} \\
(0.000)\end{array}$ & $\begin{array}{r}0.053^{* * *} \\
(0.000)\end{array}$ \\
\hline Acquisition $_{i t-1}$ & $\begin{array}{r}-0.281^{* *} \\
(0.024)\end{array}$ & $\begin{array}{r}0.012^{* *} \\
(0.012)\end{array}$ & $\begin{array}{r}0.036^{* *} \\
(0.010)\end{array}$ \\
\hline Acquisition $_{i t-2}$ & $\begin{array}{r}-0.021 \\
(0.233)\end{array}$ & $\begin{array}{r}0.009 \\
(0.208)\end{array}$ & $\begin{array}{r}0.013 \\
(0.155)\end{array}$ \\
\hline Acquisition $_{i t} *$ & 0.003 & $0.084^{* *}$ & $0.021^{* *}$ \\
\hline Firm Size & $(0.376)$ & $(0.045)$ & $(0.016)$ \\
\hline Change in Control & $0.026^{* *}$ & & 0.008 \\
\hline Pay & $(0.008)$ & & $(0.437)$ \\
\hline Percentage Share & $0.011^{* *}$ & $0.007^{* *}$ & $0.012^{* *}$ \\
\hline Ownership & $(0.015)$ & $(0.015)$ & $(0.004)$ \\
\hline CEO Tenure & $\begin{array}{r}0.000 \\
(0.112)\end{array}$ & $\begin{array}{r}0.001 \\
(0.169)\end{array}$ & $\begin{array}{r}0.014^{*} \\
(0.076)\end{array}$ \\
\hline Board Size & $\begin{array}{r}0.949^{* *} \\
(0.009)\end{array}$ & $\begin{array}{r}0.118^{* * *} \\
(0.000)\end{array}$ & $\begin{array}{r}0.022^{* * *} \\
(0.000)\end{array}$ \\
\hline $\begin{array}{l}\text { Board } \\
\text { Independence }\end{array}$ & $\begin{array}{r}-1.121^{* *} \\
(0.036)\end{array}$ & $\begin{array}{r}-0.061^{* * *} \\
(0.000)\end{array}$ & $\begin{array}{r}-0.030^{* * *} \\
(0.000)\end{array}$ \\
\hline $\begin{array}{l}\text { No. of Observations } \\
\rho\end{array}$ & $\begin{array}{r}13022 \\
0.237 \\
\end{array}$ & 13022 & 13022 \\
\hline
\end{tabular}




\section{Table 8: Acquisition Premium in CEO Pay by Acquisition Performance}

In this table we present the estimates of acquisition premium in CEO pay,correcting for the likelihood of post-acquisition CEO turnover. In columns (1) and (2) we present the estimates of the Heckman Selection model and in column (3) we report the fixed effects estimates. The dependant variables for each column is mentioned below. Here we present the results of the effect of acquisition outcomes on the pay premium using an indicator to classify bad acquisitions.

\begin{tabular}{|c|c|c|c|}
\hline \multirow[b]{2}{*}{ Parameters } & \multicolumn{2}{|c|}{ Survivor bias Corrected } & \multirow{2}{*}{$\begin{array}{c}\text { Fixed Effects } \\
(3) \\
\end{array}$} \\
\hline & $\begin{array}{c}\text { Selection } \\
\text { Equation } \\
(1)\end{array}$ & $\begin{array}{c}\text { Heckman } \\
\text { Corrected } \\
(2) \\
\end{array}$ & \\
\hline $\begin{array}{l}\text { Dependent } \\
\text { Variable }\end{array}$ & CEO Retention & Log Pay & Log Pay \\
\hline $\mathrm{ROA}_{i t}$ & $\begin{array}{r}0.036^{* * *} \\
(0.000)\end{array}$ & $\begin{array}{l}0.012^{* *} \\
(0.045)\end{array}$ & $\begin{array}{c}0.032^{*} \\
(0.059)\end{array}$ \\
\hline $\mathrm{ROA}_{i t-1}$ & $\begin{array}{l}0.028^{*} \\
(0.077)\end{array}$ & $\begin{array}{r}0.010 \\
(0.236)\end{array}$ & $\begin{array}{r}0.018^{*} \\
(0.077)\end{array}$ \\
\hline $\mathrm{MTBV}_{i t}$ & $\begin{array}{l}0.014^{*} \\
(0.011)\end{array}$ & $\begin{array}{l}0.009^{*} \\
(0.072)\end{array}$ & $\begin{array}{l}0.008^{*} \\
(0.071)\end{array}$ \\
\hline $\operatorname{MTBV}_{i t-1}$ & $\begin{array}{r}0.003 \\
(0.212)\end{array}$ & $\begin{array}{r}0.000 \\
(0.228)\end{array}$ & $\begin{array}{r}0.000 \\
(0.224)\end{array}$ \\
\hline$\sigma_{\operatorname{Re} t}$ & $\begin{array}{r}-0.011^{*} \\
(0.053)\end{array}$ & $\begin{array}{r}0.127^{* *} \\
(0.010)\end{array}$ & $\begin{array}{r}0.121^{* *} \\
(0.011)\end{array}$ \\
\hline $\begin{array}{l}\text { Firm Size } \\
\text { (Ln Sales) }\end{array}$ & $\begin{array}{c}0.033^{* *} \\
(0.044)\end{array}$ & $\begin{array}{r}0.385^{* * *} \\
(0.000)\end{array}$ & $\begin{array}{r}0.394^{* * *} \\
(0.000)\end{array}$ \\
\hline Acquisition $_{i t}$ & $\begin{array}{r}-0.351^{* * *} \\
(0.000)\end{array}$ & $\begin{array}{r}0.018^{* *} \\
(0.021)\end{array}$ & $\begin{array}{r}0.039^{* *} \\
(0.011)\end{array}$ \\
\hline Acquisition $_{i t-1}$ & $\begin{array}{r}-0.037^{* *} \\
(0.028)\end{array}$ & $\begin{array}{r}0.014^{* *} \\
(0.017)\end{array}$ & $\begin{array}{l}0.021^{* *} \\
(0.014)\end{array}$ \\
\hline Acquisition $_{i t-2}$ & $\begin{array}{r}-0.000 \\
(0.208)\end{array}$ & $\begin{array}{r}0.005 \\
(0.227)\end{array}$ & $\begin{array}{r}0.008 \\
(0.210)\end{array}$ \\
\hline Negative Return $_{i t}$ & $\begin{array}{r}-0.068^{*} \\
(0.054)\end{array}$ & $\begin{array}{r}0.009 \\
(0.296)\end{array}$ & $\begin{array}{r}0.015 \\
(0.213)\end{array}$ \\
\hline Acquisition $_{i t}{ }^{*}$ & $-0.047^{* *}$ & $-0.033^{* *}$ & -0.014 \\
\hline Negative Return $_{i t}$ & $(0.021)$ & $(0.015)$ & $(0.273)$ \\
\hline Change in Control & $0.028^{* *}$ & & 0.009 \\
\hline Pay & $(0.013)$ & & $(0.327)$ \\
\hline Percentage Share & $0.019^{* *}$ & $0.006^{* *}$ & $0.005^{* *}$ \\
\hline Ownership & $(0.026)$ & $(0.024)$ & $(0.010)$ \\
\hline CEO Tenure & $\begin{array}{r}0.002 \\
(0.187)\end{array}$ & $\begin{array}{l}0.003^{*} \\
(0.061)\end{array}$ & $\begin{array}{r}0.008^{*} \\
(0.082)\end{array}$ \\
\hline Board Size & $\begin{array}{r}0.954^{* *} \\
(0.015)\end{array}$ & $\begin{array}{r}0.137^{* *} \\
(0.024)\end{array}$ & $\begin{array}{r}0.027^{* * *} \\
(0.000)\end{array}$ \\
\hline Board & $-1.121^{* *}$ & $-0.045^{* *}$ & $-0.033^{* *}$ \\
\hline Independence & $(0.037)$ & $(0.011)$ & $(0.019)$ \\
\hline $\begin{array}{l}\text { No. of Observations } \\
\rho\end{array}$ & $\begin{array}{r}13022 \\
0.215\end{array}$ & 13022 & 13022 \\
\hline
\end{tabular}


Table 9: Acquisition Premium based on longer term acquisition performance

In this table we present the estimates of acquisition premium in $\mathrm{CEO}$ pay,correcting for the likelihood of post-acquisition CEO turnover. In columns (1) and (2) we present the estimates of the Heckman Selection model and in column (3) we report the fixed effects estimates. The dependant variables for each column is mentioned below. Here we present the results of the effect of acquisition outcomes on the pay premium using a long term metric to classify bad acquisitions.

\begin{tabular}{|c|c|c|c|}
\hline \multirow[b]{2}{*}{ Parameters } & \multicolumn{2}{|c|}{ Survivor bias Corrected } & \multirow{2}{*}{$\begin{array}{c}\text { Fixed Effects } \\
(3) \\
\end{array}$} \\
\hline & $\begin{array}{c}\text { Selection } \\
\text { Equation } \\
(1) \\
\end{array}$ & $\begin{array}{c}\text { Heckman } \\
\text { Corrected } \\
(2) \\
\end{array}$ & \\
\hline $\begin{array}{l}\text { Dependent } \\
\text { Variable }\end{array}$ & CEO Retention & Log Pay & Log Pay \\
\hline $\mathrm{ROA}_{i t}$ & $\begin{array}{r}0.028^{* *} \\
(0.010)\end{array}$ & $\begin{array}{r}0.017^{*} \\
(0.066)\end{array}$ & $\begin{array}{r}0.035^{*} \\
(0.059)\end{array}$ \\
\hline $\mathrm{ROA}_{i t-1}$ & $\begin{array}{r}0.014 \\
(0.133)\end{array}$ & $\begin{array}{r}0.013 \\
(0.267)\end{array}$ & $\begin{array}{l}0.018^{*} \\
(0.071)\end{array}$ \\
\hline $\mathrm{MTBV}_{i t}$ & $\begin{array}{l}0.015^{*} \\
(0.020)\end{array}$ & $\begin{array}{r}0.005^{*} \\
(0.055)\end{array}$ & $\begin{array}{r}0.013^{*} \\
(0.073)\end{array}$ \\
\hline $\operatorname{MTBV}_{i t-1}$ & $\begin{array}{r}0.001 \\
(0.263)\end{array}$ & $\begin{array}{r}0.001 \\
(0.205)\end{array}$ & $\begin{array}{r}0.000 \\
(0.220)\end{array}$ \\
\hline$\sigma_{\operatorname{Re} t}$ & $\begin{array}{r}-0.016^{* *} \\
(0.041)\end{array}$ & $\begin{array}{r}0.147^{* *} \\
(0.017)\end{array}$ & $\begin{array}{r}0.119^{* *} \\
(0.016)\end{array}$ \\
\hline $\begin{array}{l}\text { Firm Size } \\
\text { (Ln Sales) }\end{array}$ & $\begin{array}{r}0.043 \\
(0.134)\end{array}$ & $\begin{array}{r}0.360^{* * *} \\
(0.000)\end{array}$ & $\begin{array}{r}0.392^{* * *} \\
(0.000)\end{array}$ \\
\hline Acquisition $_{i t}$ & $\begin{array}{r}-0.334^{* *} \\
(0.017)\end{array}$ & $\begin{array}{r}0.013^{* *} \\
(0.010)\end{array}$ & $\begin{array}{r}0.035^{* *} \\
(0.014)\end{array}$ \\
\hline Acquisition $_{i t-1}$ & $\begin{array}{r}-0.112^{* *} \\
(0.032)\end{array}$ & $\begin{array}{r}0.013^{* *} \\
(0.025)\end{array}$ & $\begin{array}{r}0.022^{* *} \\
(0.015)\end{array}$ \\
\hline Acquisition $_{i t-2}$ & $\begin{array}{l}-0.001 \\
(0.258)\end{array}$ & $\begin{array}{r}0.005 \\
(0.239)\end{array}$ & $\begin{array}{r}0.007 \\
(0.223)\end{array}$ \\
\hline Negative Benchmarked & $\begin{array}{r}-0.048^{*} \\
(0.067)\end{array}$ & $\begin{array}{r}0.008 \\
(0.264)\end{array}$ & $\begin{array}{r}0.018 \\
(0.216)\end{array}$ \\
\hline $\begin{array}{l}\text { Return } i t \\
\text { Acquisition }_{i t} * \text { Negative }\end{array}$ & $\begin{aligned} &(0.066) \\
&-0.044^{* *}\end{aligned}$ & $\begin{aligned} &(0.264) \\
&-0.037^{* *}\end{aligned}$ & $\begin{array}{r}(0.216) \\
-0.005\end{array}$ \\
\hline Benchmarked Return $_{i t}$ & $(0.013)$ & $(0.014)$ & $(0.273)$ \\
\hline Change in Control & $0.028^{* *}$ & & 0.004 \\
\hline Pay & $(0.016)$ & & $(0.329)$ \\
\hline Percentage Share & $0.027^{* *}$ & $0.004^{* *}$ & $0.006^{* *}$ \\
\hline Ownership & $(0.015)$ & $(0.010)$ & $(0.014)$ \\
\hline CEO Tenure & $\begin{array}{r}0.001 \\
(0.103)\end{array}$ & $\begin{array}{l}0.004^{*} \\
(0.084)\end{array}$ & $\begin{array}{r}0.022^{* *} \\
(0.027)\end{array}$ \\
\hline Board Size & $\begin{array}{r}0.927^{* *} \\
(0.038)\end{array}$ & $\begin{array}{r}0.128^{* *} \\
(0.019)\end{array}$ & $\begin{array}{r}0.026^{* * *} \\
(0.000)\end{array}$ \\
\hline Board & $-1.113^{* *}$ & $-0.055^{* *}$ & $-0.037^{* *}$ \\
\hline Independence & $(0.030)$ & $(0.012)$ & $(0.016)$ \\
\hline $\begin{array}{l}\text { No. of Observations } \\
\rho\end{array}$ & $\begin{array}{r}13022 \\
0.226\end{array}$ & 13022 & 13022 \\
\hline
\end{tabular}




\section{Appendices \\ Appendix 1: Alternate Method of \\ Estimating Acquisition Premium}

In this table we present the estimates of acquisition premium in CEO pay, correcting for survivor bias. In columns (1) and (2) we present the estimates of the Heckman Selection model and in column (3) we report the fixed effects estimates. The dependant variables for each column is mentioned below. ${ }^{*}, * *, * * *$

indicate significance at $10 \%, 5 \%$ and $1 \%$ levels respectively.

The p-values are given in the brackets.

\begin{tabular}{|c|c|c|c|}
\hline Parameters & $\begin{array}{c}\text { Departing } \\
\text { CEOPay = } 0 \\
(1)\end{array}$ & $\begin{array}{l}\text { Baseline } \\
\text { Estimates } \\
\quad(2)\end{array}$ & $\begin{array}{c}\text { Fixed Effects } \\
(3)\end{array}$ \\
\hline $\begin{array}{l}\text { Dependent } \\
\text { Variable }\end{array}$ & Log Pay & Log Pay & Log Pay \\
\hline $\mathrm{ROA}_{i t}$ & $\begin{array}{r}0.237^{*} \\
(0.015)\end{array}$ & $\begin{array}{c}0.015^{*} \\
(0.049)\end{array}$ & $\begin{array}{r}0.038^{*} \\
(0.071)\end{array}$ \\
\hline $\mathrm{ROA}_{i t-1}$ & $\begin{array}{r}0.199^{* *} \\
(0.018)\end{array}$ & $\begin{array}{r}0.023 \\
(0.233)\end{array}$ & $\begin{array}{l}0.016^{*} \\
(0.064)\end{array}$ \\
\hline $\operatorname{MTBV}_{i t}$ & $\begin{array}{l}0.096^{*} \\
(0.069)\end{array}$ & $\begin{array}{l}0.008^{*} \\
(0.057)\end{array}$ & $\begin{array}{l}0.005^{*} \\
(0.081)\end{array}$ \\
\hline $\operatorname{MTBV}_{i t-1}$ & $\begin{array}{r}0.081 \\
(0.144)\end{array}$ & $\begin{array}{r}0.000 \\
(0.231)\end{array}$ & $\begin{array}{r}0.001 \\
(0.248)\end{array}$ \\
\hline$\sigma$ & $\begin{array}{r}0.185^{* *} \\
(0.020)\end{array}$ & $\begin{array}{r}0.126^{* *} \\
(0.003)\end{array}$ & $\begin{array}{r}0.114^{* *} \\
(0.007)\end{array}$ \\
\hline $\begin{array}{l}\text { Firm Size } \\
\text { (Ln Sales) }\end{array}$ & $\begin{array}{r}0.712^{* * *} \\
(0.000)\end{array}$ & $\begin{array}{r}0.364^{* * *} \\
(0.000)\end{array}$ & $\begin{array}{r}0.391^{* * *} \\
(0.000)\end{array}$ \\
\hline Acquisition $_{i t}$ & $\begin{array}{r}-1.357^{* * *} \\
(0.000)\end{array}$ & $\begin{array}{r}0.015^{* *} \\
(0.010)\end{array}$ & $\begin{array}{r}0.038^{* *} \\
(0.013)\end{array}$ \\
\hline Acquisition $_{i t} *$ & $-0.015^{*}$ & $0.009^{*}$ & $0.019^{* *}$ \\
\hline $\begin{array}{l}\text { Firm Size } \\
\text { Acquisition }_{i t-1}\end{array}$ & $(0.053)$ & $\begin{array}{l}(0.058) \\
0.018^{* *}\end{array}$ & $\begin{array}{l}(0.018) \\
0.031^{* *} \\
(0.025)\end{array}$ \\
\hline Acquisition $_{i t-2}$ & & $\begin{array}{c}0.009^{*} \\
(0.053)\end{array}$ & $\begin{array}{l}0.019^{* *} \\
(0.008)\end{array}$ \\
\hline $\begin{array}{l}\text { Severance Pay } \\
\text { Eligibility }\end{array}$ & $\begin{array}{r}0.024 \\
(0.281)\end{array}$ & & $\begin{array}{r}0.012 \\
(0.309)\end{array}$ \\
\hline Percentage Share & $0.038^{* *}$ & $0.001^{*}$ & $0.009^{* *}$ \\
\hline $\begin{array}{l}\text { Ownership } \\
\text { CEO Tenure }\end{array}$ & $(0.017)$ & $\begin{array}{l}(0.088) \\
0.004^{* *}\end{array}$ & $\begin{array}{l}(0.040) \\
0.007^{* *}\end{array}$ \\
\hline Board Size & $\begin{array}{c}0.287^{* *} \\
(0.015)\end{array}$ & $\begin{array}{c}(0.010) \\
0.127^{* *} \\
(0.012)\end{array}$ & $\begin{array}{r}(0.002) \\
0.028^{* * *} \\
(0.000)\end{array}$ \\
\hline Board & $-0.091^{* *}$ & $-0.051^{* *}$ & $-0.034^{* *}$ \\
\hline Independence & $(0.033)$ & $(0.016)$ & $(0.016)$ \\
\hline No. of Observations & 13022 & 13022 & 13022 \\
\hline
\end{tabular}




\section{Appendix 2: Acquisition Premium controlling for Deal Characteristics}

In this table we present the estimates of acquisition premium in CEO pay,correcting for the likelihood of post-acquisition CEO turnover. In columns (1) and (2) we present the estimates of the Heckman Selection model and in column (3) we report the fixed effects estimates. The dependant variables for each column is mentioned below. Here we present the results of the effect of acquisition outcomes on the pay premium using an indicator to classify bad acquisitions.

\begin{tabular}{|c|c|c|c|}
\hline \multirow[b]{2}{*}{ Parameters } & \multicolumn{2}{|c|}{ Survivor bias Corrected } & \multirow{2}{*}{$\begin{array}{c}\text { Fixed Effects } \\
(3) \\
\end{array}$} \\
\hline & $\begin{array}{l}\text { Selection } \\
\text { Equation } \\
(1) \\
\end{array}$ & $\begin{array}{c}\text { Heckman } \\
\text { Corrected } \\
(2)\end{array}$ & \\
\hline $\begin{array}{l}\text { Dependent } \\
\text { Variable }\end{array}$ & CEO Retention & Log Pay & Log Pay \\
\hline $\mathrm{ROA}_{i t}$ & $\begin{array}{r}0.028^{* * *} \\
(0.000)\end{array}$ & $\begin{array}{c}0.012^{*} \\
(0.067)\end{array}$ & $\begin{array}{c}0.034^{*} \\
(0.060)\end{array}$ \\
\hline $\mathrm{ROA}_{i t-1}$ & $\begin{array}{r}0.027^{*} \\
(0.079)\end{array}$ & $\begin{array}{r}0.010 \\
(0.327)\end{array}$ & $\begin{array}{c}0.016^{*} \\
(0.072)\end{array}$ \\
\hline $\mathrm{MTBV}_{i t}$ & $\begin{array}{c}0.014^{* *} \\
(0.021)\end{array}$ & $\begin{array}{r}0.009^{*} \\
(0.072)\end{array}$ & $\begin{array}{r}0.008^{*} \\
(0.070)\end{array}$ \\
\hline $\mathrm{MTBV}_{i t-1}$ & $\begin{array}{r}0.002 \\
(0.212)\end{array}$ & $\begin{array}{r}0.000 \\
(0.222)\end{array}$ & $\begin{array}{r}0.000 \\
(0.220)\end{array}$ \\
\hline$\sigma_{\operatorname{Re} t}$ & $\begin{array}{c}-0.011^{*} \\
(0.058)\end{array}$ & $\begin{array}{r}0.119^{* *} \\
(0.014)\end{array}$ & $\begin{array}{r}0.118^{* *} \\
(0.017)\end{array}$ \\
\hline $\begin{array}{l}\text { Firm Size } \\
\text { (Ln Sales) }\end{array}$ & $\begin{array}{l}0.044^{*} \\
(0.061)\end{array}$ & $\begin{array}{r}0.373^{* * *} \\
(0.000)\end{array}$ & $\begin{array}{r}0.385^{* * *} \\
(0.000)\end{array}$ \\
\hline Acquisition $_{i t}$ & $\begin{array}{r}-0.356^{* * *} \\
(0.000)\end{array}$ & $\begin{array}{r}0.018^{* *} \\
(0.021)\end{array}$ & $\begin{array}{r}0.039^{* *} \\
(0.011)\end{array}$ \\
\hline Acquisition $_{i t-1}$ & $\begin{array}{r}-0.025^{* *} \\
(0.031)\end{array}$ & $\begin{array}{r}0.016^{* *} \\
(0.026)\end{array}$ & $\begin{array}{l}0.024^{* *} \\
(0.019)\end{array}$ \\
\hline Negative Return $_{i t}$ & $\begin{array}{r}-0.077^{*} \\
(0.056)\end{array}$ & $\begin{array}{r}0.004 \\
(0.323)\end{array}$ & $\begin{array}{r}0.013 \\
(0.218)\end{array}$ \\
\hline Acquisition $_{i t} *$ & $-0.061^{* *}$ & $-0.027^{* *}$ & -0.006 \\
\hline Negative Return $_{i t}$ & $(0.011)$ & $(0.011)$ & $(0.294)$ \\
\hline Deal Size & $\begin{array}{c}0.023^{*} \\
(0.055)\end{array}$ & $\begin{array}{r}0.019^{* *} \\
(0.050)\end{array}$ & $\begin{array}{r}0.009^{*} \\
(0.073)\end{array}$ \\
\hline Cash & 0.826 & 0.003 & 0.001 \\
\hline Transaction & $(0.334)$ & $(0.224)$ & $(0.178)$ \\
\hline Severance Pay & $0.019^{* *}$ & & 0.004 \\
\hline Eligibility & $(0.017)$ & & $(0.343)$ \\
\hline Percentage Share & $0.011^{* *}$ & $0.001^{* *}$ & $0.003^{* *}$ \\
\hline Ownership & $(0.020)$ & $(0.013)$ & $(0.011)$ \\
\hline CEO Tenure & $\begin{array}{r}0.001 \\
(0.204)\end{array}$ & $\begin{array}{c}0.004^{*} \\
(0.088)\end{array}$ & $\begin{array}{r}0.009^{*} \\
(0.060)\end{array}$ \\
\hline Board Size & $\begin{array}{r}0.956^{* *} \\
(0.013)\end{array}$ & $\begin{array}{r}0.118^{* *} \\
(0.021)\end{array}$ & $\begin{array}{r}0.022^{* * *} \\
(0.000)\end{array}$ \\
\hline Board & $-1.117^{* *}$ & $-0.044^{* *}$ & $-0.035^{* *}$ \\
\hline Independence & $(0.039)$ & $(0.010)$ & $(0.013)$ \\
\hline No. of Observations & 13022 & 13022 & 13022 \\
\hline$\rho$ & 0.233 & & \\
\hline
\end{tabular}




\section{Appendix 3: Acquisition Premium-Alternate Classification of Negative Returns}

CEO pay, correcting for survivor bias. In columns (1) and (2) we present the estimates of the Heckman Selection model and in column (3) we report the fixed effects estimates. The dependant variables for each column is mentioned below. *, **, ***

indicate significance at $10 \%, 5 \%$ and $1 \%$ levels respectively. The p-values are given in the brackets.

\begin{tabular}{|c|c|c|c|}
\hline \multirow[b]{2}{*}{ Parameters } & \multicolumn{2}{|c|}{ Survivor bias Corrected } & \multirow{2}{*}{$\begin{array}{c}\text { Fixed Effects } \\
\text { (3) }\end{array}$} \\
\hline & $\begin{array}{c}\text { Selection } \\
\text { Equation } \\
\quad(1)\end{array}$ & $\begin{array}{c}\text { Heckman } \\
\text { Corrected } \\
(2)\end{array}$ & \\
\hline $\begin{array}{l}\text { Dependent } \\
\text { Variable }\end{array}$ & CEO Retention & Log Pay & Log Pay \\
\hline $\mathrm{ROA}_{i t}$ & $\begin{array}{r}0.034^{* * *} \\
(0.000)\end{array}$ & $\begin{array}{c}0.012^{*} \\
(0.059)\end{array}$ & $\begin{array}{c}0.032^{*} \\
(0.068)\end{array}$ \\
\hline $\mathrm{ROA}_{i t-1}$ & $\begin{array}{r}0.027^{* *} \\
(0.019)\end{array}$ & $\begin{array}{r}0.010 \\
(0.354)\end{array}$ & $\begin{array}{r}0.018^{*} \\
(0.077)\end{array}$ \\
\hline $\mathrm{MTBV}_{i t}$ & $\begin{array}{l}0.014^{*} \\
(0.057)\end{array}$ & $\begin{array}{r}0.006^{*} \\
(0.071)\end{array}$ & $\begin{array}{r}0.008^{*} \\
(0.074)\end{array}$ \\
\hline $\mathrm{MTBV}_{i t-1}$ & $\begin{array}{r}0.010 \\
(0.244)\end{array}$ & $\begin{array}{r}0.000 \\
(0.218)\end{array}$ & $\begin{array}{r}0.001 \\
(0.227)\end{array}$ \\
\hline$\sigma$ & $\begin{array}{r}-0.008^{*} \\
(0.060)\end{array}$ & $\begin{array}{r}0.119^{* *} \\
(0.005)\end{array}$ & $\begin{array}{r}0.115^{* *} \\
(0.003)\end{array}$ \\
\hline $\begin{array}{l}\text { Firm Size } \\
\text { (Ln Sales) }\end{array}$ & $\begin{array}{l}0.038^{*} \\
(0.059)\end{array}$ & $\begin{array}{r}0.373^{* * *} \\
(0.000)\end{array}$ & $\begin{array}{r}0.385^{* * *} \\
(0.000)\end{array}$ \\
\hline Acquisition $_{i t}$ & $\begin{array}{r}-0.348^{* * *} \\
(0.000)\end{array}$ & $\begin{array}{c}0.017^{* *} \\
(0.012)\end{array}$ & $\begin{array}{r}0.039^{* *} \\
(0.010)\end{array}$ \\
\hline Negative Return $_{i t}$ & $\begin{array}{r}-0.096^{* *} \\
(0.045)\end{array}$ & $\begin{array}{r}0.012 \\
(0.198)\end{array}$ & $\begin{array}{r}0.018 \\
(0.232)\end{array}$ \\
\hline Acquisition $_{i t} *$ & 0.008 & $0.078^{* *}$ & -0.017 \\
\hline Negative Return $_{i t}$ & $(0.408)$ & $(0.015)$ & $(0.163)$ \\
\hline Acquisition $_{i t-1}$ & $\begin{array}{r}-0.022^{* *} \\
(0.034)\end{array}$ & $\begin{array}{r}0.016^{* *} \\
(0.013)\end{array}$ & $\begin{array}{r}0.024^{* *} \\
(0.019)\end{array}$ \\
\hline Acquisition $_{i t-2}$ & $\begin{array}{r}-0.004 \\
(0.208)\end{array}$ & $\begin{array}{r}0.009^{* *} \\
(0.033)\end{array}$ & $\begin{array}{r}0.017^{* *} \\
(0.012)\end{array}$ \\
\hline Severance Pay & $0.019^{* *}$ & & 0.008 \\
\hline Eligibility & $(0.010)$ & & $(0.318)$ \\
\hline Percentage Share & $0.014^{* *}$ & $0.001^{* *}$ & $0.003^{* *}$ \\
\hline Ownership & $(0.023)$ & $(0.017)$ & $(0.011)$ \\
\hline CEO Tenure & $\begin{array}{r}0.003 \\
(0.189)\end{array}$ & $\begin{array}{r}0.006^{*} \\
(0.081)\end{array}$ & $\begin{array}{l}0.009^{*} \\
(0.064)\end{array}$ \\
\hline Board Size & $\begin{array}{r}0.973^{* *} \\
(0.014)\end{array}$ & $\begin{array}{r}0.111^{* *} \\
(0.018)\end{array}$ & $\begin{array}{r}0.022^{* * *} \\
(0.000)\end{array}$ \\
\hline $\begin{array}{l}\text { Board } \\
\text { Independence }\end{array}$ & $\begin{array}{r}-1.132^{* *} \\
(0.045)\end{array}$ & $\begin{array}{r}-0.047^{* *} \\
(0.021)\end{array}$ & $\begin{array}{r}-0.035^{* *} \\
(0.013)\end{array}$ \\
\hline $\begin{array}{l}\text { No. of Observations } \\
\rho\end{array}$ & $\begin{array}{r}13022 \\
0.221\end{array}$ & 13022 & 13022 \\
\hline
\end{tabular}

